\title{
ЕКОНОМIЧНА TEOPIЯ
}

УДК 336.741.222

JEL Classification: E59

Срешко Ю. О.

канд. економ. наук, доцент ORCID ID: 0000-0002-9161-8820

Гафаров Е. М. ORCID ID: 0000-0003-2154-531X

Національний технічний університет Украӥни "Київський політехнічний інститут імені Ігоря Сікорського”

\section{ІМПЛЕМЕНТАЦІЯ ІНДЕКСОВАНОЇ ОДИНИЦІ ВАРТОСТІ В УКРАЇ̈I}

\section{IMPLEMENTATION OF THE INDEXED UNIT OF ACCOUNT IN UKRAINE}

Індексована одиниия вартості є виокремленням функиії грошей міри вартості, щзо захищцє иую функиію від впливу інфляиії, будучи підв'язаною до індексу споживчих цүін або іншого цінового індексу. Завдяки иій властивості індексована одиничя вартості також є дієвим інструментом у боротьбі з такими явищами: хаотичним ціноутворенням, знеціненням довгострокових контрактів та угод, іпотечних та інших довгострокових кредитів та депозитів, державних облігачій та зборів, які можуть бути викликаними інфляиією. Імплементація індексованої одиниці вартості буде корисною для будь-якої краӥни у довгостроковій перспективі. У статті досліджено, як імплементація цзього інструменту в Украӥні, яка є країною, якій останні десятиріччя властива галопуюча інфлячія, може допомогти впоратися із специфічними економічними проблемами нашого суспільства, викликаними інфляцією, базуючись на іноземному досвіді та результатах застосування індексованої одиниці вартості. Розглянуто можливе застосування індексованої одинииі вартості в банківській системі, а саме те, як вона може збільшити довіру до банківської системи, пожвавити депозитну діяльність банків та, завдяки иььму, змінити структуру грошової маси в країні. Досліджено механізм індексованих іпотечних кредитів та те, як їх імплементація заохотить внутрішні та зовнішні інвестиції у низько розвинений іпотечний ринок в Украӥні, зробить іпотечні кредити більи доступними та зможе збільшити вартість недооціненої за паритетом купівельної спроможності валюти відносно інших валют. А також розглянуто те, як індексована одиниия вартості може бути застосована задля розвитку та збільшення інвестицій у ринок облігацій внутрішньої державної позики та інші можливі сфери застосування індексованої одиниці вартості. $У$ статті запропонована методологія для застосування індексованої одиниці вартості. Розглянуто сфери ї̈ використання, залежно від індексу, за яким вона буде розраховуватися. Надані дві формули для 
обрахування вартості індексованої одиниці вартості у відповідності до методології Державної служби статистики України та проаналізована різниия між ними.

Ключові слова: індексована одиниця вартості, міра вартості, інфляція, індексація, банківська система, іпотека, облігації державної позики.

Indexed unit of account is the separation of measure of value function of money from other functions. It secures this function from inflation being pegged to the consumer price index or other price indices. Being unaffected by inflation, indexed unit of account is as well an efficient instrument in fighting with chaotic pricing, depreciation of long-term deals and contracts, mortgage and other long-term loans and deposits, and government bonds. Implementation of indexed unit of account could benefit any country in long-term prospective. Ukraine is not a country with a stable economy. It mostly faces galloping inflation with an average annual rate of $12.36 \%$ since the year 2000. During that period, the index of consumer prices increased by 9.5 times. Due to this, any long-term deals, deposits, mortgages, and investments contracted in the nominal currency of our country are risked losing their real value. Therefore, there occur many socio-economic issues. Namely, these are redistribution of income between employees and entrepreneurs in favour of the latter, social and political instability, violation of the process of social production, narrowing of the market and effective demand of the population, reduction of investments, violation of credit relations and banking, devaluation of savings. Additionally, it causes reduction of real incomes, especially of such social groups as pensioners, persons living on social insurance payments, all fixed-income employees, including government employees, scientists, students, etc. Some of the above problems could be solved or at least reduce the inflationary impact on them by introducing an indexed unit of account in the country. The purpose of this article is studying the motivation of implementation of indexed unit of account in Ukraine, possible scopes of application and its benefits. This paper researches how the implementation of indexed unit of account in Ukraine might solve some specific economic issues of our society as distrust of the banking system, low level of development of mortgage and bond markets. Additionally, there are presented the methodology of usage of indexed unit of account and formulas for computing its value adapted to the methodology of State Statistics Service of Ukraine.

Key words: indexed unit of account, unit of account, inflation, indexation, banking system, mortgage, government bonds.

Вступ. Зважаючи на те, що вітчизняна економіка тенденційно не характеризується стабільністю, будь-які довгострокові угоди, депозити, інвестиції, що були укладені та здійснені у номінальних грошових одиницях (гривнях), піддавалися, піддаються та, можливо, будуть піддаватися ризику втрати їхньої реальної вартості [1, с. 6]. Статистично це виражається у тому, що Україна стикається з інфляцією, що носить, здебільшого, галопуючий характер, рівень якої з 2000 року становить у середньому $12,36 \%$ на рік. Зокрема, за цей період були лише 5 років, коли приріст інфляції був менший за 5\% на рік, а індекс споживчих цін із 2000 до кінця 2019 року збільшився в 9,5 разів. [2, с. 8-9]. Це, в свою чергу, 
призводить до низки соціально-економічних та суспільних проблем: перерозподіл доходів між найманими робітниками та підприємцями на користь останніх, зменшення реальних доходів населення (особливо таких соціальних груп, як пенсіонери, особи, які живуть за рахунок виплат по соціальному страхуванню, усі працівники з фіксованим доходом, зокрема службовці державних установ, науковці, студенти та ін.), соціальна та політична нестабільність, порушення процесу суспільного виробництва, звуження ринку збуту та платоспроможного попиту населення, скорочення інвестицій, порушення кредитних відносин та банківської діяльності, знецінення заощаджень [3, с. 166-169]. Деякі 3 вищезазначених проблем можна вирішити чи принаймні зменшити інфляційний вплив на них шляхом введення в державі індексованої одиниці вартості.

Теоретичні засади та досвід історичного застосування IOB у країнах Латинської Америки були досліджені нами попередньо у [1], вони також виступають предметом широкого наукового доробку Роберта Шиллера [17]; детальне дослідження застосування IOB для іпотечних кредитів та досвід такого застосування у Мексиці розглянуті у статті Джозефа Ліпскомба, Джона Харві та Гарольда Ханта [11]; переваги та недоліки інфляційно-індексованих облігацій державної позики розглянуті у статті Пу Шеня [13].

Постановка завдання. Мета статті полягає у дослідженні можливості і доцільності імплементації IOB в Україні, потенційних сфер практичного застосування та переваг, які можуть бути досягнуті в результаті, а також, у аналізі методологічних засад запровадження IOB 3 урахуванням методології вітчизняної Державної служби статистики.

Методологія статті базується на аналізі досвіду застосування індексованої одиниці вартості в інших країнах та його екстраполяції на умови української економіки з урахуванням іiї особливостей.

Результати дослідження. Сфери застосування. Банківська система. Однією з головних причин введення ІОВ у Чилі в 1967 році було знецінення боргів у наслідок гіперінфляції [4]. А тому однією з головних сфер застосування IOB є індексація внутрішнього державного боргу, а також банківських кредитів та депозитів. Застосування IOВ у банківській сфері могло б поліпшити ситуацію із суспільною недовірою до банків [1, c. 6].

Першим вагомим чинником формування недовіри до банківської системи можна вважати те, що при проведенні широкомасштабної структурної грошової реформи у 90-х роках минулого століття майже усі заощадження населення, що зберігалися в Ощадному банку, були 
повністю знецінені через те, що не були проіндексовані [3, с. 183]. Сума втрат українців від знецінення цих заощаджень, у відповідності до Закону України «Про державні гарантії відновлення заощаджень громадян України» (1997 рік), складає 131,96 млрд грн та, як визначено цим законом, подальша компенсаційна індексація заощаджень громадян здійснюється при видачі вкладів, страхових внесків, погашенні цінних паперів відповідно до індексу інфляції [5]. На погашення цієї заборгованості з 1997 до 2013 року було виділено лише 16,5 млрд грн через системну нестачу коштів у бюджеті.

Також серйозним чинником недовіри до банківської системи послугував нещодавній так званий «банкопад» 2014-2017 pp., коли 3 01.01.2014 до 01.01.2018 під час економічної кризи у наслідок агресивної політики Національного Банку України кількість діючих банків скоротилася на 98 банків [6]. У наслідок цього загальна сума акцептованих кредиторських вимог сягнула майже 266 млрд грн, 3 яких вкладникам виплатили 90 млрд грн станом на 2019 рік [7].

Обидві ці проблеми супроводжувалися гострими національними політичними та економічними кризами. І якщо друга проблема пов'язана 3 державним банківським регулюванням та недоброчесністю власників та акціонерів деяких банків й носить політичний характер, то перша $\epsilon$ наслідком не індексації заощаджень населення під час грошової реформи.

Саме тому введення індексованих депозитів за допомогою IOB (далі - індексовані депозити) лише частково вирішить проблему недовіри до банків. Але, абстрагуючись від політичної складової, на нашу думку, це буде неодмінно корисним явищем.

Один 3 можливих варіантів моделі індексованих депозитів наданий нами у статті «Індексована одиниця вартості»: «Для цього можна застосовувати чилійську модель, описану вище, коли початкова сума депозиту переводиться в IOB за актуальним курсом на той день. На цю суму нараховуються відсотки, та при виводі вона конвертується в гривню. Чилійська модель спиралася на розсуди Джевонса, при індексуванні депозитів строком від трьох місяців, вважаючи, що на менших проміжках часу інфляція не матиме серйозного впливу. Проте, вводячи індексовані депозити в Україні, нами рекомендується індексувати й місячні депозити. Це не є надскладною процедурою та ще більше забезпечило б їх від ризиків знецінення (до прикладу, у 2015 році місячний приріст інфляції в березні та квітні становив 10,8\% і 14\% відповідно)» [1, с. 6-7]. Також слід зазначити, що відсоткова ставка за індексованими кредитами, депозитами тощо за ІСЦ має бути меншою, аніж ставка за номінальними. Оскільки вартість ІОВ за ІСЦ одразу розраховується з урахуванням 
інфляції, то ऑiі рівень має відніматися від номінальної ставки, роблячи відсоткову ставку за індексованими кредитами, депозитами реальною.

Висока інфляція навесні 2015 року була спричинена валютними спекуляціями внаслідок зростання попиту на валюту через рішення Національного Банку про відмову від індикативного курсу гривні та формування iï валютного курсу на підставі об'єктивних параметрів ринкового попиту та пропозиції [8], чому передувало багато чинників. Окрім того, однією з причин «банкопаду» $\epsilon$ те, що вкладники під час кризи активно переводили свої заощадження в готівку та обмінювали на іноземну валюту. І це $є$ лише одним з випадків прояву особливості нашої економіки, коли люди невпевнені у національній валюті та банківській системі й більш схильні до того, аби зберігати свої заощадження не на депозитах, а у іноземній валюті «під матрацом». За даними Національного Банку, обсяг готівки в іноземній валюті поза банками сягає 86 млрд доларів [9] (близько 2,3 трлн грн). Ця сума значно перевищує значення грошового агрегату М3, який на червень 2020 року становить 1,61 трлн грн [10].

Введення індексованих депозитів за правильної комунікації може заохотити людей класти свої заощадження на депозити. Також, оскільки ці депозити будуть підв'язані до рівня інфляції, то вони зберігатимуть свою реальну вартість. Таким чином, під час кризи та суспільної невпевненості у економічній стабільності люди б не хотіли вивести свої заощадження в готівку та обміняти на іноземну валюту, а навпаки залишали би свої внески на індексованих депозитах та навіть клали б свої інші готівкові заощадження, аби вони не втратили своєї реальної вартості [1, с. 7].

Окрім того, розміщення на індексованих депозитах хоча б частки такого колосального ресурсу, як готівка в іноземній валюті поза банками, дозволило $б$ суттєво змінити структуру грошової маси, зменшивши питому вагу агрегату М0 у агрегаті М3. Це, в свою чергу, означало б збільшення ефективності та розвиток національної грошової системи.

Збільшення коштів на депозитах буде сприяти розвитку та пожвавленню національної економіки. Оскільки це $є$ спрямуванням заощаджень населення на фінансові ринки, на які підприємства будуть звертатися за кредитами, використовуючи ці кошти на інвестування. Тобто чим більше коштів буде розміщено на депозитах, тим більшим буде обсяг інвестицій. Це, в свою чергу, призведе до того, що обсяг ВНП буде збільшуватися, причому на суму більшу від збільшення інвестицій як наслідок ефекту мультиплікатору інвестицій.

Іпотечний ринок. Сфера іпотечного кредитування та інвестицій у іпотечний ринок є основною сферою використання IOB у Мексиці, що 
дозволило знизити ризики дефолту, колапсу на ринку іпотечного кредитування та інфляційні ризики.

Механізм індексованих іпотечних кредитів на основі IOB був таким, що при їх оформленні ціна предмету іпотеки переводилася у IOB на день заключення договору i встановлювалася реальна відсоткова ставка (оскільки IOB сам по собі прив'язаний до інфляції, то відсоток встановлюється без коригування на інфляційні ризики), яка нараховувалася також у ІОВ. Виплати за кожний період були визначеними в IOB і сплачувалися в законному платіжному засобі (національній валюті) у відповідності до його вартості до IOB.

Оскільки індексоване кредитування нівелює ризики втрати реальної вартості та невизначеності, то це збільшує попит на інвестиції в іпотечний ринок, які є довгостроковими, не тільки з боку внутрішніх інвесторів, а й 3 боку іноземних. Як було зазначено у дослідженні Дж. Ліпскомба, Дж. Харві та Г. Ханта «Exchange-Rate Risk Mitigation with Price-Level-Adjusting Mortgages: The Case of the Mexican UDI» закордонні інвестори часто побоюються валютних ризиків у зв'язку з небажаними змінами курсу, особливо в країнах, де курс може різко змінитися, знецінивши реальну вартість інвестицій, проте введення індексованого кредитування здатне зменшити валютні ризики, заохочуючи закордонних інвесторів [11, с. 29]. Також у рамках цього дослідження проводилась симуляція, коли доларові інвестори вкладали кошти у мексиканські іпотечні кредити, отримуючи більший реальний дохід у доларах, аніж реальна відсоткова ставка за іпотекою у Мексиці; а за умови інвестування у періоди, коли мексиканський песо був недооціненим по відношенню до долару за паритетом купівельної спроможності, реальні доходи інвесторів у доларах ставали ще більшими [11, с. 35$]$.

За даними The Economist, за паритетом купівельної спроможності гривня $\epsilon$ однією 3 найбільш недооцінених валют світу, будучи недооціненою до долару на 58,1\% та до євро на 48\% станом на січень 2020 року [12]. Такий рівень недооцінки національної валюти був би дуже привабливим для іноземних інвесторів у індексовані іпотечні кредити, не просто нівелюючи валютні ризики, а створюючи високий рівень реального доходу в іноземній валюті.

Збільшення попиту на інвестиції в іпотечні кредити без сумніву були б корисними для розвитку національного іпотечного ринку, де лише третина банків надають іпотечні кредити. Низький попит на іпотеку серед українців можна пов'язати з високою ставкою за цим видом кредиту. Аналогічна проблема 3 високою ставкою спостерігалась у Мексиці, де населення не мало змоги оформити іпотеку, хоча й бажало покращити 
свою житлові умови. Висока вартість іпотеки зменшувала і якість, i кількість пропозиції житла. Введення індексованих кредитів та збільшення іноземних інвестицій дозволяє збільшити ефективність цього ринку, конкуренцію та пропозицію. Це ж призведе до того, що реальні відсоткові ставки мають зменшитись, а житло має стати доступнішим [11, c. 37]. За умови збільшення доступності цього ринку він $\epsilon$ дуже перспективним, оскільки велика частка українців живуть у будівлях, побудованих ще за радянських часів, i, маючи можливість, покращили би свої житлові умови.

Варто також зазначити, що макроекономічним наслідком збільшення іноземних інвестицій буде те, що недооцінена за паритетом купівельної спроможності, гривня буде збільшувати свою вартість відносно іноземних валют до того рівня, який би відповідав іiі теоретичній купівельній спроможності, зважаючи на те, що статистично вона вважається однією з найбільш недооцінених валют світу [11, с. 37].

Облігащії державної позики. Індексування облігацій державної позики за допомогою IOB (далі - індексовані облігації) використовується в Чилі й Уругваї. Цей процес за суттю $є$ аналогічним до індексованих у відповідності до інфляції облігацій (далі - інфляційно-індексовані облігації), які використовуються у США, Великій Британії, Канаді, Австралії, Сврозоні, Швеції та інших країнах.

Механізм індексованих облігацій є таким, що сума виплати за облігацією встановлюється в ІОВ у відповідності до реальної відсоткової ставки, а у день виплати переводиться в законний платіжний спосіб і виплачується тримачу облігації.

У статті «Benefits and Limitations of Inflation Indexed Treasury Bonds» розглядалися переваги інфляційно-індексованих облігацій. Головною перевагою довгострокових державних інфляційно-індексованих облігацій для інвесторів $\epsilon$ впевненість у тому, що заборгованість буде гарантовано виплачена й реальна вартість вкладень також гарантовано буде збільшеною. Це $є$ неодмінно цікавим для будь-якого інвестора, але особливо для тих, які не мають досвіду інвестування [13, с. 44], наприклад, для звичайного населення, яке зацікавлене у збільшенні реальної вартості своїх заощаджень у майбутньому, але не має достатніх знань, можливостей або впевненості для інвестування у цінні папери, які можуть не зберегти свою реальну вартість. Для Міністерства фінансів перевагою випуску інфляційно-індексованих облігацій $\epsilon$ також убезпечення своїх коштів від впливу інфляції: випускаючи довгострокові облігації з високою номінальною ставкою у період високої інфляції, Міністерство фінансів буде вимушене повертати тримачам облігацій 
більше грошей у реальному вираженні в періоди, коли інфляція буде меншою [13, с. 45].

Інвестування в облігації державної позики вигідне й доступне для людей, які готові вкладати значні кошти. Перевагою ж облігацій над депозитами $\epsilon$ те, що державні цінні папери звільнені від податку на доходи фізичних осіб (підпункт 165.1.2 Податкового кодексу України) [14]. Але станом на 09.06.2020 частка ОВДП, яку тримають фізичні особи, становить лише 0,82\%, що у грошовому виразі становить 7,21 млрд грн [15], що може означати невпевненість або недовіру до цього інструменту. Проте, як вже було зазначено, населення володіє значним грошовим ресурсом у валюті «під матрацом» [9]. За умови довіри та впевненості у цьому інструменті та тому, що він збереже реальну вартість вкладень шляхом введення індексованих облігацій, фізичні особи можуть витіснити нерезидентів 3 цього ринку, зберігаючи процент 3 цінних паперів усередині країни.

Інше. Також на практиці IOB застосовується для індексації суми пенсій, допомоги на дитину. В Україні ці трансфертні платежі індексуються у відповідності до зміни прожиткового мінімуму (у 2020 році - 3 рази). Визначення їх фіксованого розміру в реальному вираженні в IOB, окрім збереження їхньої купівельної спроможності, дозволить не визначити їх вручну та не записувати це у проект бюджету щороку.

У податковій системі можливе підв'язування до IOB неоподатковуваного мінімуму доходів громадян, розмір якого - 17 грн був встановлений у вересні 1996 році та з того часу не змінювався, незважаючи на зменшення купівельної спроможності гривні в 15,5 разів ${ }^{1} 3$ того часу. Цим неоподаткованим мінімумом також визначаються розміри штрафів за порушення закону. Їх збільшення, можливо, змогло б підвищити громадську свідомість та зменшити кількість порушень закону.

У Чилі IOB також використовується для індексації суми аліментів. В Україні наразі, у відповідності до ст. 80 Сімейного Кодексу України, розмір аліментів визначається судом у твердій грошовій формі, а змінений він може бути також тільки за рішенням суду [16]. Визначення обсягу аліментів у реальному виразі в IOB дозволить зменшити кількість судових справ зі зміни їх розміру.

Також у Чилі дозволяється використання IOB при визначенні виплат за корпоративними угодами, аби зберегти їх реальну вартість у часі особливо для довгострокових, - зменшуючи ризики для сторінпідписантів.

${ }^{1}$ розраховано авторами на основі статистичних даних [2] 
Методологія імплементації ІОВ. Увесь викладений матеріал 3 методології ІОВ є лише пропозиціями авторів. Усі рішення про IOB індекс, формули, початкове відношення між гривнею та IOB, період та частота, з якою визнається це відношення, - мають бути затверджені на законодавчому рівні.

Індекс. ІОВ за суттю - це інструмент, який виконує функцію міри вартості та щоденно індексується до законного платіжного засобу у відповідності до цінового індексу. У Чилі та всіх інших країнах, які застосовують IOB, вона підв'язана до індексу споживчих цін (далі - ICЦ), за яким безпосередньо визначають й рівень інфляції. Це є безпосереднім призначенням, яке від самого початку закладалося в цей інструмент. Проте в Уругваї існують дві IOB, Unidad Readjustable та Unidad Previsional, які базуються на індексі реальної заробітної плати (далі IPЗП). Переваги застосування IOB на базі IPЗП, а також причини для імплементації та сфери застосування обох IOB в державі розглянуті Робертом Шиллером у статті «Indexed Units of Account for the United States»:

- IOB на базі ІСЦ: використовується для визначення цін на товари, продаж яких займає довгий проміжок часу після запропонування ціни (наприклад, нерухомість);

- IOB на базі ІРЗП: використовується для визначення суми трансфертних платежів держави громадянам, плати за іпотечним кредитами, за ануїтетними виплатами, а також можливе використання для визначення заробітної плати, наприклад, для державних службовців [17].

Причиною використання двох IOB може також слугувати той факт, що вони змінюються не однаково, особливо у кризові періоди, коли інфляція збільшується, а реальні доходи скорочуються. На рис. 1 зображена зміна значення ІСЦ та ІРЗП до їхнього значення станом на 01.01.2010, якщо ми припускаємо, що на цю базову дату їх значення дорівнюе 1. 


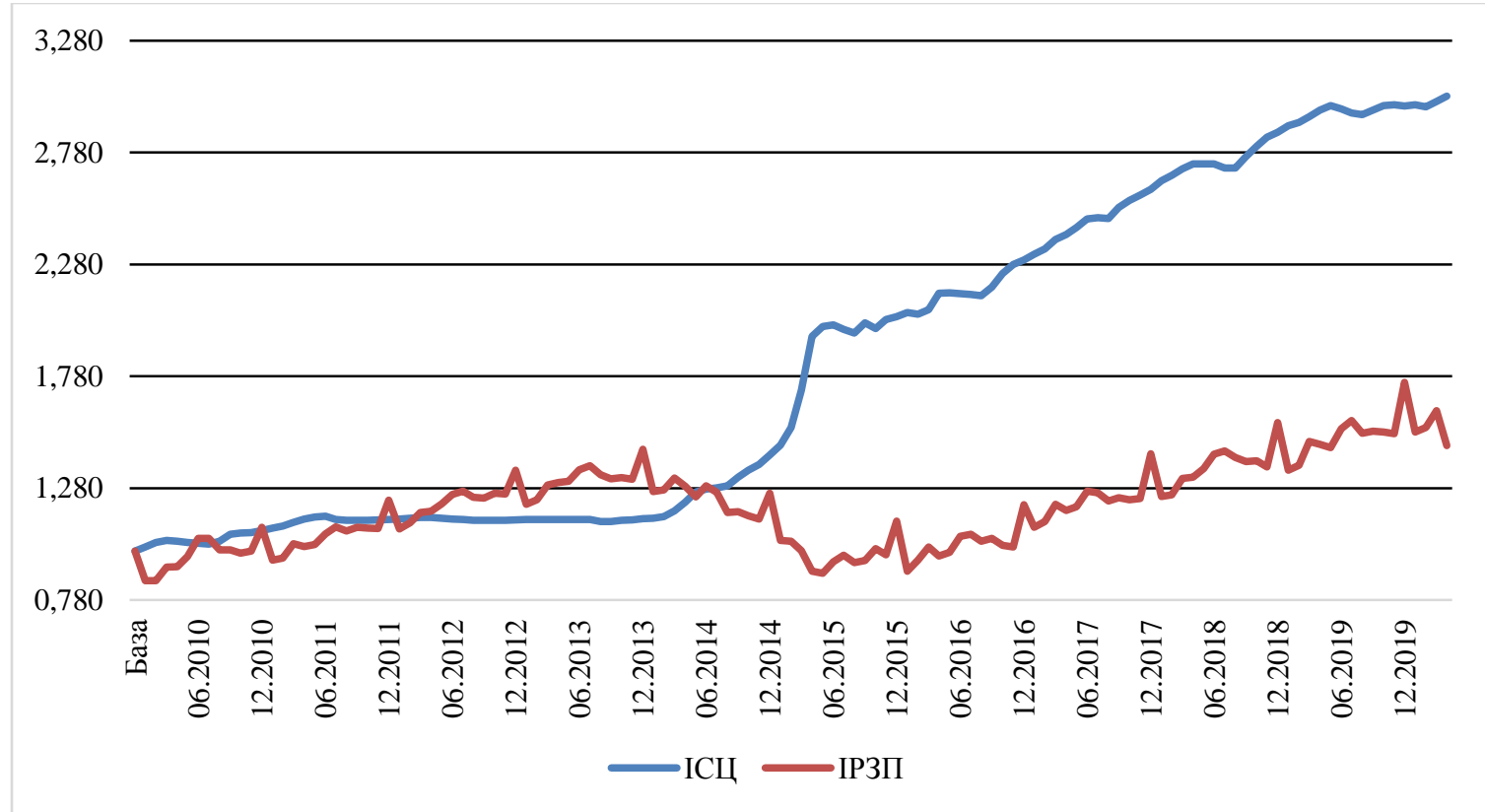

\section{Рисунок 1. Зміна ІСЦ та ІРЗП з 01.01.2010}

Джерело: побудовано на основі статистичних даних [2, с. 8-9; 18]

Формула. Після визначення індексів, на основі яких буде визначатися вартість IOB відносно законного платіжного засобу, варто визначити формулу, за якою ця вартість буде обраховуватися. Аналізуючи досвід країн, які застосовують IOB, загальна формула має наступний вигляд:

$$
\mathrm{IOB}_{d+n, m}=\mathrm{IOB}_{d, m} *\left(\frac{\bigsqcup_{m-1}}{\bigsqcup \mathrm{I}_{m-2}}\right)^{\frac{n}{D_{m}}}
$$

де $I O B_{d, m}$ - вартість IOВ в день $d$ місяця $m, Ц I_{m-1}-$ значення цінового індексу місяця $m-1, D_{m}-$ кількість днів в місяці $m$.

Проте, на відміну від статистичної методології латиноамериканських країн, в Україні ІСЦ та ІРЗП рахуються не як абсолютні величини, а одразу як відношення до ІСЦ та IРЗП минулого місяця, а тому формула, за умови публікації даних про зміну індексу в перший день місяця, спрощується до такого вигляду:

$$
\mathrm{IOB}_{d+n, m}=\mathrm{IOB}_{d, m} *\left(3 \mathrm{I}_{m-1}\right)^{\frac{n}{D_{m}}}
$$

де $I O B_{d, m}$ - вартість IOB в день $d$ місяця $m, 3 Ц I_{m-1}$ - зміна цінового індексу за місяць $m-1, D_{m}-$ кількість днів в місяці $m$. 
Дані про зміну ІСЦ публікуються 11 числа наступного місяця, а тому періодом для обрахування значення IOB можуть бути дні з 11 числа поточного місяця до 10 числа наступного місяця. Якщо все це формалізувати, то формула IOB за ICЦ в Україні матиме наступний вигляд:

$$
\operatorname{IOB}_{d, m}=\left\{\begin{array}{c}
\operatorname{IOB}_{10, m-1} *\left(\mathrm{IC}_{m-2}\right)^{\frac{D_{m-1}-10+d}{D_{m-1}}}, 1 \leq d \leq 10 \\
\operatorname{IOB}_{10, m} *\left(\mathrm{IC}_{m-1}\right)^{\frac{d-10}{D_{m}}}, 11 \leq d \leq D_{m}
\end{array}\right.
$$

де $I O B_{d, m}$ - вартість IOВ в день $d$ місяця $m, I C Ц_{m-1}-$ зміна ICЦ за місяць $m-1, D_{m}-$ кількість днів в місяці $m$.

Також Р. Шиллером у статті «Indexed Units of Account for the United States» [17] запропонована наступна формула, яка носить лінійний характер, на відміну від формул (1), (2), (3), що носять лог-лінійний характер:

$$
\text { Unit }_{d, m}=\frac{\text { Index }_{m-3} *\left(D_{m}-d\right)+\text { Index }_{m-2} * d}{D_{m}}
$$

де Unit $_{d, m}$ - вартість IOB в день $d$ місяця $m$, Index I-2 $_{m}$ - значення цінового індексу в місяць $m-2, D_{m}-$ кількість днів в місяці $m$.

Проте, як і в країнах Латинської Америки, які застосовують IOB, значення цінових індексів у США $\epsilon$ абсолютними величинами, а не відносними, як в Україні. А тому, адаптуючи формулу (4) до української методології визначення ІСЦ отримаємо наступну формулу:

$$
\begin{aligned}
& \mathrm{IOB}_{d, m}= \\
& \left\{\begin{array}{c}
\mathrm{IOB}_{10, m-1} *\left(1-\frac{D_{m-1}-10+d}{D_{m-1}} *\left(1-\mathrm{IC}_{m-2}\right)\right), 1 \leq d \leq 10 \\
\operatorname{IOB}_{10, m} *\left(1-\frac{d-10}{D_{m}}\left(1-\mathrm{IC}_{m-1}\right)\right), 11 \leq d \leq D_{m}
\end{array}\right.
\end{aligned}
$$

де $I O B_{d, m}$ - вартість IOВ в день $d$ місяця $m, I C Ц_{m-1}$ - зміна ICЦ за місяць $m-1, D_{m}-$ кількість днів в місяці $m$.

Також однією з необхідних компонент формули IOB є визначення іiі початкової вартості щодо законного платіжного способу. Якщо б в 
Україні 10.02.2020 ввели б ІОВ за ІСЦ та встановили б початкову вартість 1 IOB за 1 гривню, то, використовуючи статистичні дані та застосовуючи формули (3) i (5), могли б визначити вартість IOB з 11.02.2020 до 10.07.2020. Результати таких розрахунків зображені на рис. 2:

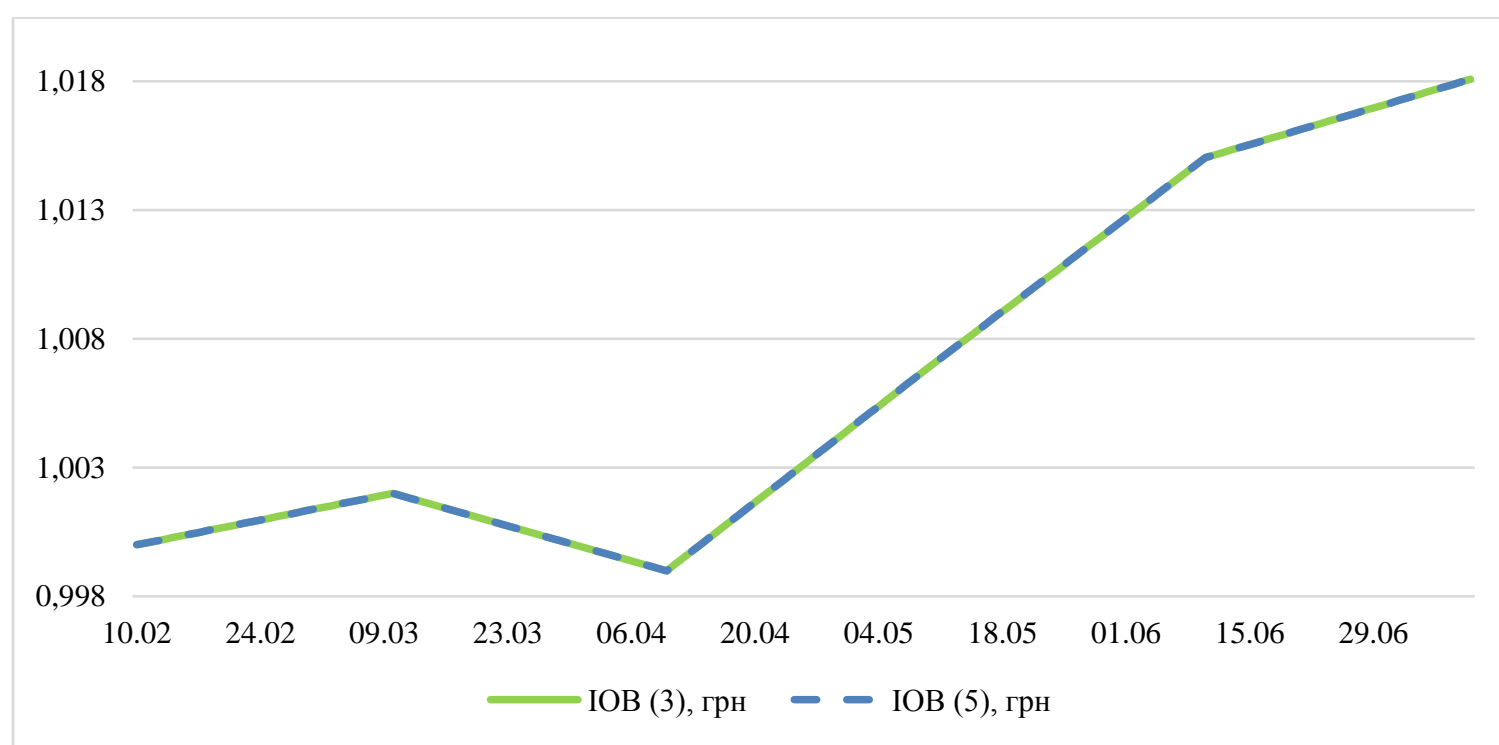

Рисунок 2. Вартість гіпотетичного українського IОВ за формулами (3) та (5) авторів

Джерело: побудовано на основі статистичних даних [2, с. 8-9] та розрахунків

За відносно низького рівня місячної інфляції та майже одиничного відношення між IOB та законним платіжним засобом різниця між результатами, отриманими 3 першої та другої формул, зводиться до мільйонних, як на цьому графіку. А 10 числа кожного місяця їхні значення будуть однаковими. Проте протягом місяця значення IOB за формулою (5) буде завжди - i при інфляції, і при дефляції - більшим за значення IOB, розрахованим за формулою (3).

Висновки. Дослідивши потенційні сфери застосування IOB в Україні, можна стверджувати, що цей інструмент сприяв би розвитку банківської сфери, іпотечного ринку, облігацій внутрішньої державної позики, а також був би корисним у соціальній сфері, дозволив би нівелювати інфляційні ризики при укладанні корпоративних угод. IOB може стати «вбудованим» стабілізатором інфляції. Також була запропонована методологія для української IOB: було обгрунтовано використання IOB за ICЦ та IРЗП, виведено дві формули IOB 3 урахуванням методології Державної служби статистики, змодельована іiі поведінка у першому півріччі 2020 року. 


\section{Література:}

1. Срешко Ю. О., Гафаров Е. М. Індексована одиниця вартості. Ефективна економіка. 2020. № 5. - URL: http://www.economy.nayka.com.ua/?op=1\&z=7912 (дата звернення: 31.07.2020).

2. Статистичний збірник "Індекси споживчих цін за 2019 рік" [Електронний ресурс] / За ред. Жук I. М. - 2020 - Режим доступу до ресурсу: http://www.ukrstat.gov.ua/druk/publicat/kat_u/2020/zb/03/zb_ISC_2019.pdf.

3. Гроші та Кредит : підручник/ М. І. Савлук та ін. 6-те вид., перероб. і допов. Київ: KHEУ, 2011. $589 \mathrm{c}$.

4. Valor de la UF. Valor de la UF : веб-сайт. URL: https://valoruf.cl/ (дата звернення: 31.07.2020).

5. Про державні гарантії відновлення заощаджень громадян України : Закон України від 21 лис. 1996 р. № 537/96-BP. URL: https://zakon.rada.gov.ua/laws/show/537/96$\% \mathrm{D} 0 \% \mathrm{~B} 2 \% \mathrm{D} 1 \% 80$ (дата звернення: 31.07.2020).

6. Количество банков в Украине (2008-2020). Мінфін : веб-сайт. URL: https://index.minfin.com.ua/banks/stat/count/ (дата звернення: 31.07.2020).

7. В Україні з 2014 року внаслідок ліквідації банків вкладникам виплатили понад 90 млрд грн. 112 Украӥна : веб-сайт. URL: https://ua.112.ua/ekonomika/v-ukraini-z-2014roku-vnaslidok-likvidatsii-bankiv-vkladnykam-vyplatyly-ponad-90-mlrd-hrn-492021.html (дата звернення: 31.07.2020).

8. Національний банк змінює підходи до проведення грошово-кредитної політики, одночасно посилюючи іï жорсткість. Національний Банк Украӥни : веб-сайт. URL: https://bank.gov.ua/ua/news/all/pravlinnya-natsionalnogo-banku-ukrayini-shvalilo-nizkurishen-dlya-stabilizatsiyi-groshovo-kreditnogo-rinku-na-osnovi-rekomendatsiy-komitetuz-monetarnoyi-politiki-7582 (дата звернення: 31.07.2020).

9. Физлица могут стать крупнейшими инвесторами в госдолг. StockWorld : веб-сайт. URL: $\quad$ https://www.stockworld.com.ua/ru/news/fizlitsa-moghut-stat-krupnieishimiinviestorami-v-ghosdolgh\# (дата звернення: 31.07.2020).

10. Огляд фінансових корпорацій. Наџіональний Банк Украӥни : файл. URL: https://bank.gov.ua/files/3.1-Monetary_Statistics.xlsx (дата звернення: 31.07.2020).

11. Lipscomb J. B., Harvey J. T., Hunt H. Exchange-Rate Risk Mitigation with Price-LevelAdjusting Mortgages: The Case of the Mexican UDI. Journal of Real Estate Research. 2003. Vol. 25, №1. P. 23-41.

12. BigMac Index. The Economist : веб-сайт. URL: https://www.economist.com/news/2020/01/15/the-big-mac-index (дата звернення: 31.07.2020).

13. Pu Shen. Benefits and limitations of inflation indexed Treasury bonds. Economic Review. 1995. Vol. 80, №3, P. 41-56.

14. Податковий кодекс України: Закон України від 2 груд. 2010 р. № 2755-VI. URL: https://zakon.rada.gov.ua/laws/show/2755-17 (дата звернення: 01.08.2020).

15. ОВДП, які знаходяться в обігу за номінально-амортизаційною вартістю. Наиіональний Банк України : веб-сайт. URL: https://bank.gov.ua/ua/markets/t-bills (дата звернення: 01.08.2020).

16. Сімейний кодекс України: Закон України від 10 січ. 2002 р. № 2947-III. URL: https://zakon.rada.gov.ua/laws/show/2947-14 (дата звернення: 01.08.2020). 
17. Shiller R. J. Indexed Units of Account for the United States. Yale Department of Economics : веб-сайт. URL: http://www.econ.yale.edu/ shiller/online/uf-usa4.html

18. Індекс інфляції в Україні 2020. Мінфін : веб-сайт. URL: https://index.minfin.com.ua/ua/economy/index/inflation/ (дата звернення: 01.08.2020).

\section{References:}

1. J. Yereshko and E. Hafarov, "Indexed unit of account," Efektyvna ekonomika, no. 5, 2020, May 2020, [Online]. Available: http://www.economy.nayka.com.ua/?op=1\&z=7912 (Accessed 31 July 2020).

2. Consumer Price Indices In 2019: Statistical Publication. Kyiv, Ukraine: State Statistics Service of Ukraine [Online]. Available: http://www.ukrstat.gov.ua/druk/publicat/kat_u/2020/zb/03/zb_ISC_2019.pdf (Accessed 31 July 2020).

3. Savluk M. I. et al, "Money and Credit", $6^{\text {th }}$ ed. Kyiv, Ukraine: KNEU, 2011.

4. "Valor de la UF." Valor de la UF. https://valoruf.cl/ (Accessed 31 July 2020).

5. Verkhovna Rada of Ukraine. (1996, Nov. 21). №537/96, On government guaranties of citizens' savings restoration. [Online]. Available: https://zakon.rada.gov.ua/laws/show/537/96-\%D0\%B2\%D1\%80 (Accessed 31 July 2020).

6. The number of banks in Ukraine (2008-2020). Minfin, 2020. [Online]. Available: https://index.minfin.com.ua/banks/stat/count/ (Accessed 31 July 2020).

7. "Since 2014, over 90 bln hryvnia were returned to depositors due to the banks liquidation in Ukraine." 112 Ukraine. https://ua.112.ua/ekonomika/v-ukraini-z-2014-roku-vnaslidoklikvidatsii-bankiv-vkladnykam-vyplatyly-ponad-90-mlrd-hrn-492021.html (Accessed 31 July 2020).

8. "National Bank of Ukraine changes approaches to monetary policy, simultaneously making it stricter." National Bank of Ukraine. https://bank.gov.ua/ua/news/all/pravlinnyanatsionalnogo-banku-ukrayini-shvalilo-nizku-rishen-dlya-stabilizatsiyi-groshovokreditnogo-rinku-na-osnovi-rekomendatsiy-komitetu-z-monetarnoyi-politiki-7582 (Accessed 31 July 2020).

9. "Individuals might become the largest investors in the public debt." StockWorld. https://www.stockworld.com.ua/ru/news/fizlitsa-moghut-stat-krupnieishimi-inviestoramiv-ghosdolgh\# (Accessed 31 July 2020).

10. Review of financial corporations. National Bank of Ukraine, Jul. 2020. [Online]. Available: https://bank.gov.ua/files/3.1-Monetary_Statistics.xlsx (Accessed 31 July 2020).

11. J. B. Lipscomb, J. T. Harvey, and H. Hunt, "Exchange-Rate Risk Mitigation with PriceLevel-Adjusting Mortgages: The Case of the Mexican UDI," JRER, vol. 25, no. 1., pp. 2341, 2003.

12. "BigMac Index." The Economist. https://www.economist.com/news/2020/01/15/the-bigmac-index (Accessed 31 July 2020).

13. Pu Shen, "Benefits and limitations of inflation indexed Treasury bonds". Econ. Rev., vol. 80, no. 3, pp. 41-56, 1995.

14. Verkhovna Rada of Ukraine. (2010, Dec. 2). №2755-VI, Tax Code of Ukraine. [Online]. Available: https://zakon.rada.gov.ua/laws/show/2755-17 (Accessed 1 August 2020).

15. Domestic government bonds in circulation by outstanding nominal volume. National Bank of Ukraine, Jul. 2020. [Online]. Available: https://bank.gov.ua/ua/markets/t-bills (Accessed 1 August 2020). 
16. Verkhovna Rada of Ukraine. (2002, Jan. 10). №2947-III, Family Code of Ukraine. [Online]. Available: https://zakon.rada.gov.ua/laws/show/2947-14 (Accessed 1 August 2020).

17. R. J. Shiller. "Indexed Units of Account for the United States". Yale Department of Economics. http://www.econ.yale.edu/ shiller/online/uf-usa4.html

18. Inflation index in Ukraine. Minfin, Jul. 2020. [Online]. Available: https://index.minfin.com.ua/ua/economy/index/inflation/ (Accessed 1 August 2020)

УДК 336.741.222

JEL Classification: G320

I. М. Крейдич, доктор економ. наук., професор ORCID ID: 0000-0002-4594-2160

Національний технічний університет України “Київський політехнічний інститут імені Ігоря Сікорського”

Ю. О. Срешко, канд. економ. наук, доцент ORCID ID: 0000-0002-9161-8820 Національний технічний університет України “Киїський політехнічний інститут імені Ігоря Сікорського”

B. Р. Товмасян, канд. економ. наук ORCID ID: 0000-0002-1802-8939 ПВНЗ «Європейський університет»

\section{СУТНІСТЬ ТА ЕКОНОМІЧНА ПРИРОДА ФІНАНСОВОЇ ПОЛТТИК ПІДПРИЕМСТВА}

\section{THE ESSENCE AND ECONOMIC NATURE OF THE ENTERPRISE FINANCIAL POLICY}

Лексична неоднозначність в трактуванні понять $i$ категорій притаманна вітчизняній наущі в процесі пізнання нею термінології із західних наукових праць. У прочесі інтерпретації проявляється редукціонізм або, навпаки, розширення сутності, щуо змінюе розуміння категорії як синонімічно, так $i$ по суті. Кейнсіанське «термінологічний гармидар» досі панує у вітчизняній науковій думці, провокуючи невірне тлумачення термінів $i$, як наслідок, неоднозначне розуміння сутності понять, a відповідно $i$ логічну неможливість якісного аналізу системи $i$ процесів, щцо призводить до помилкової інтерпретації, ставить під сумнів теоретичну цінність дослідження, а іноді $i$ зовсім нівелює існуючий науковий доробок. Доведено, щзо категорія «фінансова політика» являє собою складну систему, елементи якоӥ взаємодіють між собою, а система набуває своїх специфічних характеристик в 